\title{
SEISMIC STRAIN MAP IN MALAYSIA DERIVED FROM LONG-TERM GLOBAL POSITIONING SYSTEM DATA
}

\author{
M. S. Mohamad, W. A. W. Aris, N. J. Jaffar*, R. Othman \\ Geomatic Innovation Research Group, Faculty of Build Environment and Surveying, 80310 Skudai Johor, Malaysia - \\ ssanimohamad@gmail.com, wananom@utm.my, jehanjaffar@gmail.com, rusliothman@utm.my
}

KEY WORDS: Global Positioning System (GPS), Seismic, Strain map, Crustal Deformation, Fault Line

\begin{abstract}
:
Series of major earthquakes struck the Sundaland plate as a result of convergence with neighboring plates such as Indian, Australian and Philippine plates. Since then, the Sundaland is experiencing significant crustal deformation that implicate reactivation of local fault and embark question on the status of geohazard and seismic risk. In Malaysia, crustal deformation study by using Global Positioning System (GPS) has been conducted for many years. However, the information of crustal deformation was reported separately and difficult to be archived. In addition, continuous estimation of crustal deformation derived from GPS has to be carried out in order to provide present day seismic status. This study aims at generating a seismic catalog map in Malaysia derived from approximately nine (9) years of GPS data. In this study, derived long-term crustal deformation in the form of coordinate time series (CTS) were converted into yearly strain map. The changes of strain with respect to location of old and active fault line in Malaysia were properly analysed. From the result, the highest changes of strain rate for Peninsular Malaysia happened in 2004 until 2005 and 2012 until 2013 prior to 2004 Acheh earthquake event with the moment magnitude (Mw) and 2012 two strike-slip events in Northern Sumatera with the magnitude of $8.2 \mathrm{Mw}$ and $8.6 \mathrm{Mw}$. In North Borneo region, the most significant changes of strain rate happened from 2007 to 2009 and 2011 to 2013. It can be expected that the results will be beneficial in augmenting geohazard mitigation in Malaysia.
\end{abstract}

\section{INTRODUCTION}

Seismic events such as earthquake have caused many catastrophes all around the world and they can be considered among the most destructive and terrifying natural hazards. In recent decades, researchers has focused progressively to respond to the public requests for information on seismic events (Bauer et al., 2014). The importance of making science understandable to non-experts is also based on the evidence that more effective public policies on scientific matters can arise from more informed and aware citizens (Durant et al., 1989). Such information also acts on the likelihood that an at-risk population will take self-protective measures (Paton et al., 2003).

Nowadays there are several past seismic event database that enables for determination of earthquake's trend (Yazdi et al., 2010). The USGS rapidly disseminates this information to National and international agencies, scientists and the general public (Guy et al., 2010). This sparks on how much the importance of the seismic catalog can contribute to the public in term of geohazard and risk management.

The Sundaland block, that includes Indochina (Vietnam, Laos, Cambodia, Thailand and Malaysia), the Sunda shelf, Borneo, Sumatra and Java, is the southeastern extremity of the vast zone of Asia affected by the continental collision between India and Asia (Chamoot-Rooke et al., 1999). According to the Advance National Seismic System (ANSS), the western edge of Sunda plate (Sumatran plate boundary) was seismically inactive from 1963 to 2003 (Feng et al., 2015). However, this region has been extremely active along this decade following the Sumatra-
Andaman earthquake on 26th December 2004 at 9.1Mw, Nias Simeulue, Sumatra on 28th March, 2005 at $8.5 \mathrm{Mw}$, Bengkulu, Sumatra on 12 September, 2007 at $7.9 \mathrm{Mw}$, and Indian Ocean earthquake on 11th April, 2012 at 8.6Mw (Wan Aris et al., 2018). A 7.5Mw earthquake have struck Central Sulawesi on 28th September 2018 has raised the anxiety of the community on the dangers of natural disasters and doubts whether this sort of disaster may befall us (Komoo et al., 2018

Seismic activity in Malaysia seems to be mild compared to neighboring country such as Indonesia. Despite that, moderate earthquakes still occurred in some part of Malaysia. The Department of Mineral and Geoscience Malaysia (DMGM) filed a report claiming there was an incident that involves a loud noise and suspected to be tremor occurrence at nearby quarry in Simpang Pulai, Perak. The department conducted an investigation immediately however there was no blasting activities carried out in the suspected area during the event (The Ministry of Water, Land and Natural Resources., 2018). Similar mild tremor events were recorded in Bukit Tinggi during 30th November 2007, however there were no reports of damaged properties (Shuib et al., 2009).

Crustal deformation study by using Global Positioning System (GPS) has been conducted in Malaysia for more than a decade. However the information of crustal deformation were documented separately and difficult to be archived especially for geohazard and risk management.

In this study, the initial goal is to gather all events from available and reliable sources for a criterion which cover all Malaysia region. These information were reviewed and

\footnotetext{
* Corresponding author
} 
interpreted in the form of seismic catalog. The result expected to be valuable for a wide variety of crustal deformation and seismic-related study as well as references for geohazard management for the public.

An initiation work were taken to compile and update crustal deformation information in the form of seismic catalog such as dynamic strain map in Malaysia. Nevertheless, the dynamic strain map enables categorizing seismic zone within the area that will be useful for geohazard management public awareness on geohazard and earthquake in Malaysia could be achieved.

\section{METHODOLOGY}

The methodology is arranged in three (3) phases as shown in Figure 1. Phase 1 provides the methodology on the site velocity estimation. The procedure on strain map generation and analysis is explained in Phase 2. Finally, Phase 3 focuses on the seismic catalog web platform design.

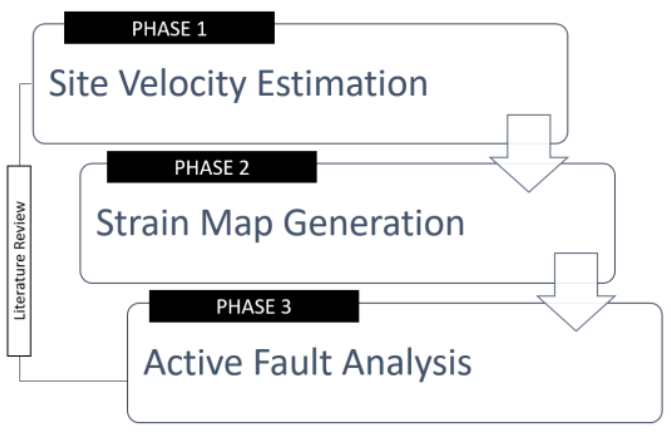

Figure 1. Methodology flow

The work as illustrated in Figure 2 involved three (3) stages; stage 1) GPS-derived CTS collected for data input; stage 2) Data screening on the acquired GPS-derived CTS; and stage 3) Site velocity estimated that represent as data input for next phases.

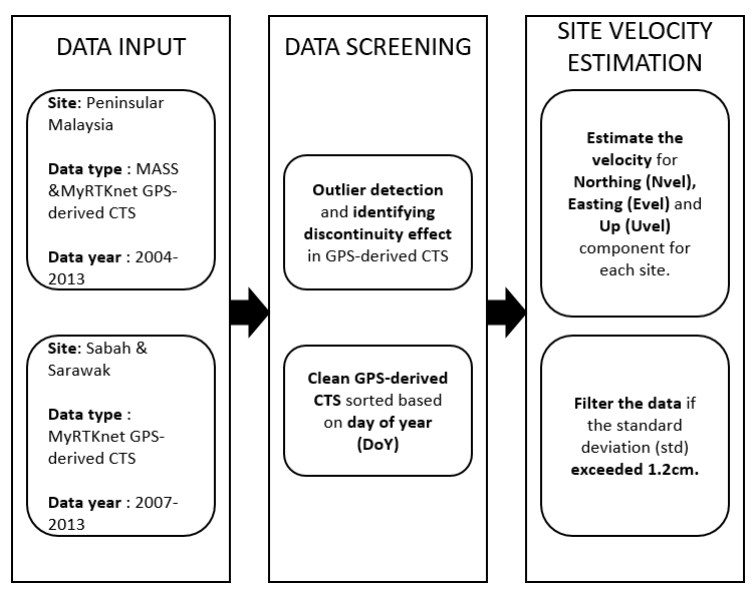

Figure 2. Phase 1: Site velocity estimation

The GPS-derived CTS attained from MASS and MyRTKnet stations that comprised of observation period from 2004-2013 were utilised. The information sorted periodically based on day of year (DoY). Next, the outlier and discontinuity are detected and removed in order to develop clean GPS-derived GPS. From the clean GPS-derived CTS, the velocity of each site that comprises of Northing (Nvel), Easting (Evel) and Up (Uvel) component were estimated as in Figure 3.

The strain map generation was divided into two areas which is Peninsular Malaysia and East Malaysia (Sabah and Sarawak) as illustrated in Figure 4. From Figure 4, Quasi Network's grid was generated to cover inland area of Peninsular Malaysia, and Sabah and Sarawak. Peninsular Malaysia consists of 144 points while 197 points in Sabah and Sarawak. The rotation of the margin grid is parallel to the Universal Transverse Mercator (UTM) grid.
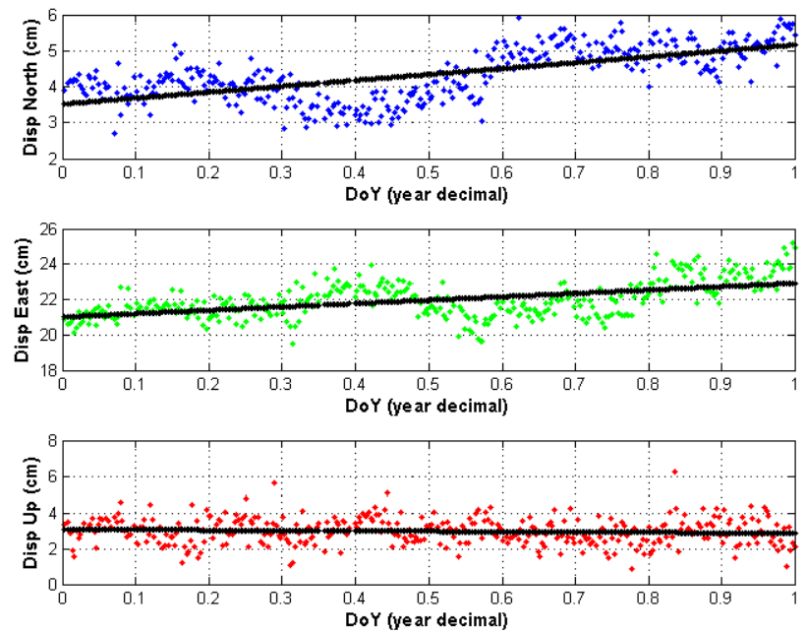

Figure 3. Graph for site velocity estimation based on GPSderived CTS

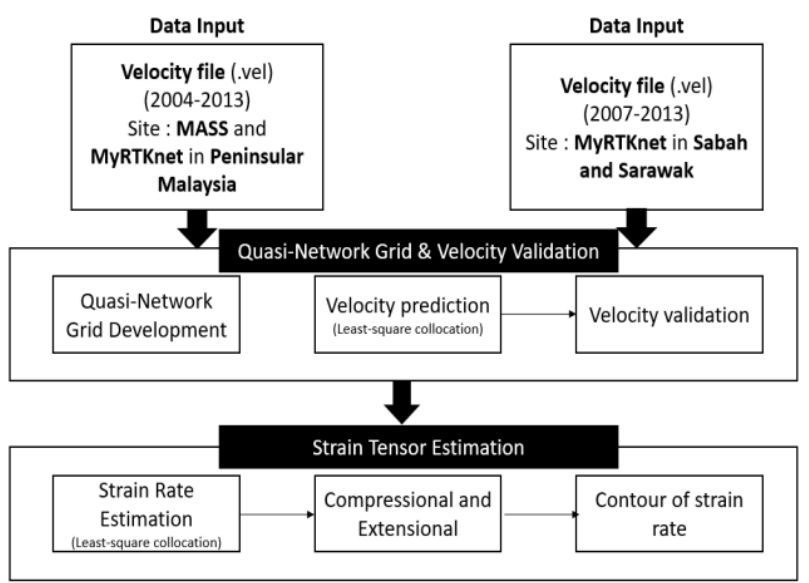

Figure 4. Phase 2: Strain map generation

By using Geostrain software (Gourdarzi et al., 2015) as in Figure 5, the study conducted velocity validation process on observed site velocities by applying spatial least square collocation. The computed velocities were compared with the estimated velocities. The revision on the horizontal and vertical covariance function were essential if the residual exceeded 1 $\mathrm{cm} /$ year.

The strain estimation on Quasi-Network grid were carried by applying strain rate collocation computation. Extensional and compressional value were computed for each Quasi-Network grid point and then overlaid on the local faults map to reveal significant of compression and extension at each point. The 
strain rate value were utilized in order to generate contour on the study area. Strain generation for Peninsular Malaysia, and Sabah and Sarawak were performed separately. The change of compression, extensional, strain and rotation rates were uses to classify the activation of local faults in the regions. In addition, the program in MATLAB software were developed in order to generate the strain map.
In next phase, the analysis on the major faults in Malaysia were conducted accordingly as illustrated in Figure 6. As mentioned before, the strain map consists of Quasi-Network grid points and overlaid major faults in Malaysia. The analysis conducted on strain rate changes of each Quasi Network point that intersected on the major faults. Further analysis of Phase 3 will be discussed in result and discussion section.

2 Geodynamic Strain Analysis Software (GeoStrain

$\begin{array}{cllllllll}\text { Stations } & \text { Lat (") } & \text { Long (") } & V_{n}(m m / y r) & V_{e}(m m / y r) & V_{u}(m m / y r) & q_{V n} & q_{e} & q_{v}\end{array}$

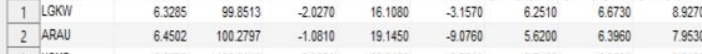

$\begin{array}{llllllll}6.4502 & 100.2197 & -1.0810 & 19.1450 & -90760 & 5.6220 & 63960 & 7.9530 \\ 5.3578 & 100.3040 & 3.9560 & 222190 & -37340 & 5.7400 & 6.2620 & 8.2126\end{array}$

$\begin{array}{llllllll}6.0296 & 100.4036 & 28540 & 18.1330 & 0.7990 & 5.8750 & 6.1780 & 7.7866\end{array}$

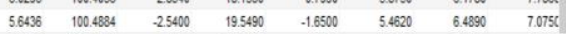

$\begin{array}{llllllll}5.1467 & 100.4937 & 28710 & 24.3140 & 1.0370 & 5.6240 & 6.3580 & 7.8346\end{array}$

$\begin{array}{llllllll}6.4622 & 100.5063 & -1.8570 & 17.7860 & -2.7190 & 5.8730 & 6.6550 & 7.8026\end{array}$

$\begin{array}{llllllll}4.2070 & 100.5592 & 26880 & 24.8940 & 1.3930 & 5.6690 & 6.3900 & 7.622\end{array}$

$\begin{array}{llllllll}5.8099 & 100.7289 & 4.8000 & 225280 & -52130 & 5.5890 & 7.8910 & 7.995 \\ 38128 & 1008164 & -13400 & 239390 & 0.0460 & 53360 & 65290 & 7280\end{array}$

$\begin{array}{llllllll}3.8128 & 100.8164 & -1.3400 & 239390 & 0.0460 & 5.3860 & 652290 & 7282 C \\ 39913 & 1010538 & -1.1040 & 242130 & -122860 & 54910 & 62900 & 75916\end{array}$

$\begin{array}{llllllll}3.9913 & 101.0538 & -1.1040 & 242130 & -1.22860 & 5.4910 & 62900 & 7.5916 \\ 492238 & 1010680 & 22160 & 240030 & -16130 & 58490 & 62220 & 8.1406\end{array}$

$\begin{array}{rrrrrrrr}4.9238 & 101.0680 & 2.2160 & 24.0030 & -1.6130 & 5.8490 & 6.2220 & 8.140 C \\ 5.4390 & 101.1303 & 0.6700 & 20.5440 & -10.1630 & 52900 & 6.8620 & 8.842 C\end{array}$

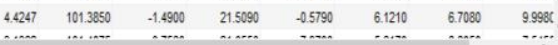

Outpout data

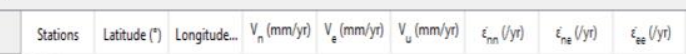

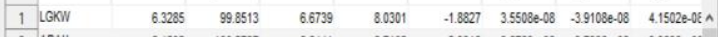

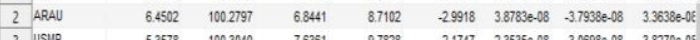

$\begin{array}{llllllll}5.3758 & 100.3040 & 7.6361 & 9.7628 & -2.1747 & 235358-08 & -3.06988-08 & 3.82700-08\end{array}$

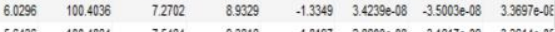

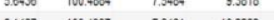

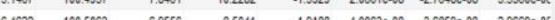

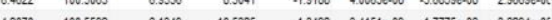

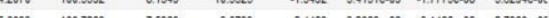

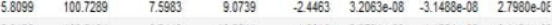

$\begin{array}{llllllll}3.8128 & 100.8164 & 82448 & 10.5511 & -1.6010 & -3.97946-09 & -1.12516-08 & 3.11246-0.08\end{array}$

$\begin{array}{llllllll}3.9913 & 101.0538 & 8.3603 & 10.8020 & -1.9024 & -2.231938-10 & -1.11188-08 & 253656-08\end{array}$

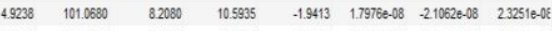

$\begin{array}{llllllll}5.4390 & 101.1303 & 7.9649 & 9.6558 & -3.1468 & 271386-08 & -2.54446-08 & 202816-08 \text {, }\end{array}$

VEL_2013_PW vel(4 statons)

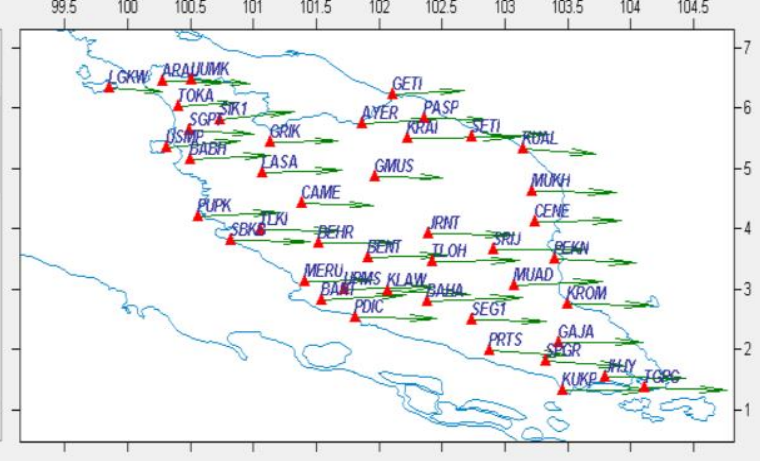

Covarianse function: $f(x)=\mathrm{a} \cdot \exp \left(-\mathrm{b} \cdot \mathrm{x}^{-2}\right)$

Coefficients:

$\begin{aligned} \text { North: } a & =4.000000(m / \mathrm{yr}))^{-2} \\ b & =0.000002(1 / 100 \mathrm{~km}) \cdot 2\end{aligned}$

Arelation length: 550.0000000 (1000

ast: $\begin{aligned}a=4.000000(=\mathrm{m} / \mathrm{yr}))^{-2} \\ b=0.000002\end{aligned}$

correlation length: 550.000000 (1000

North-Zast: $\begin{aligned} \mathrm{a}=4.000000(\mathrm{~m}=/ \mathrm{yr}) \times 2 \\ \mathrm{~b}=0.000002(1 / 100 \mathrm{~km}) * 2\end{aligned}$

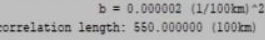

Covariance funct:

$\mathrm{Up}_{\mathrm{p}}: \mathrm{a}=5.000000(\mathrm{~m} / \mathrm{yz}) \sim 2$

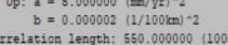

Stra

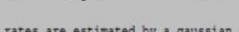

Han rates are estimated by a oaussian covariance function for observation boints usino the least-

Postion: 000 6654, 101,3988

Figure 5. Geostrain software in MATLab environment (Gourdarzi et al., 2015)

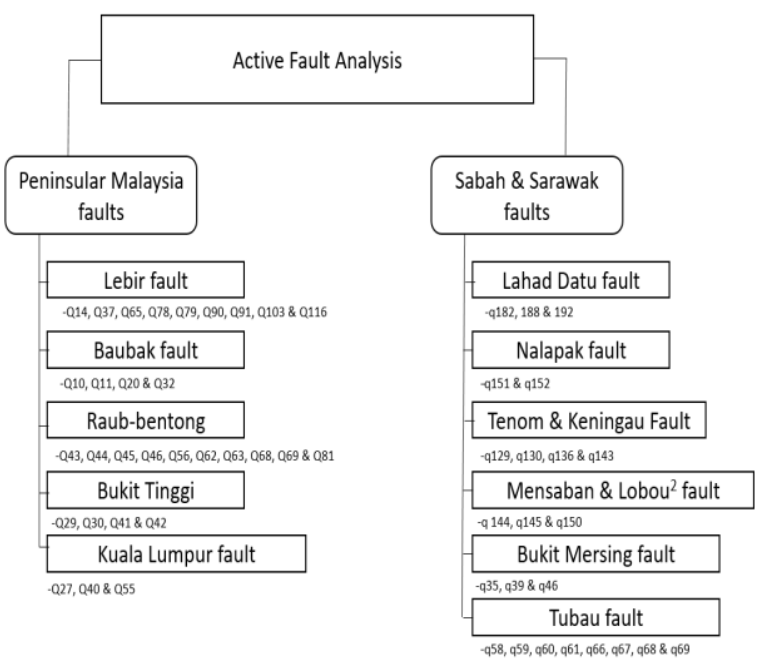

Figure 6. Phase 3: Active fault analysis with its QuasiNetwork points prior to the major faults.

\section{RESULTS AND DISCUSSION}

Adjusted coordinate in cartesian coordinate ITRF2008 that has been generated for the 3285 days of daily solution for site MASS and MyRTKnet were used. Site KUKP in 2007 was chosen for demonstration for the discussion on the outlier detection and removal as shown in Figure 3.1. The CTS is separated in three (3) local topocentric components which is north, east and up. From the Figure 7, it can be examined that there are outliers (marked in red circles) in the GPS-derived CTS of KUKP. The standard deviations at site KUKP shows $14.2 \mathrm{~mm}, 20 \mathrm{~mm}$ and $37.6 \mathrm{~mm}$ in north, east and up components respectively. These outliers were detected and removed for the case of sigma greater than $12 \mathrm{~mm}$.

After removal of these outliers, the precision was significantly increased. Figure 8 shows CTS of site KUKP for 2007 after the removal of outliers with new standard deviation at $9 \mathrm{~mm}, 8.2 \mathrm{~mm}$ and $10.5 \mathrm{~mm}$ for north, east and up components respectively. Similar method was applied to all GPS-derived CTS from MASS and MyRTKnet sites. By following the work conducted by Wan Aris (2018), these outliers were detected and removed for the case of sigma greater than $12 \mathrm{~mm}$ which resulted better precision for all GPS-derived CTS for every component. 

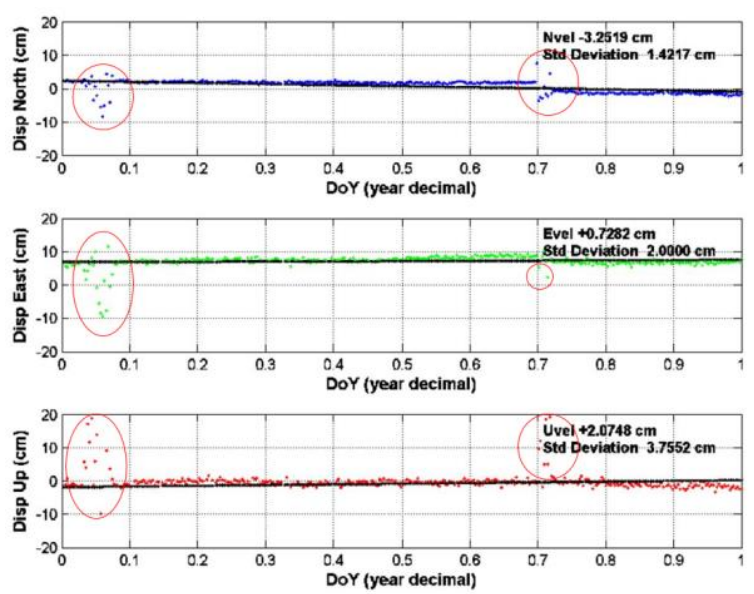

Figure 7. GPS-derived CTS at KUKP before removal of outliers.
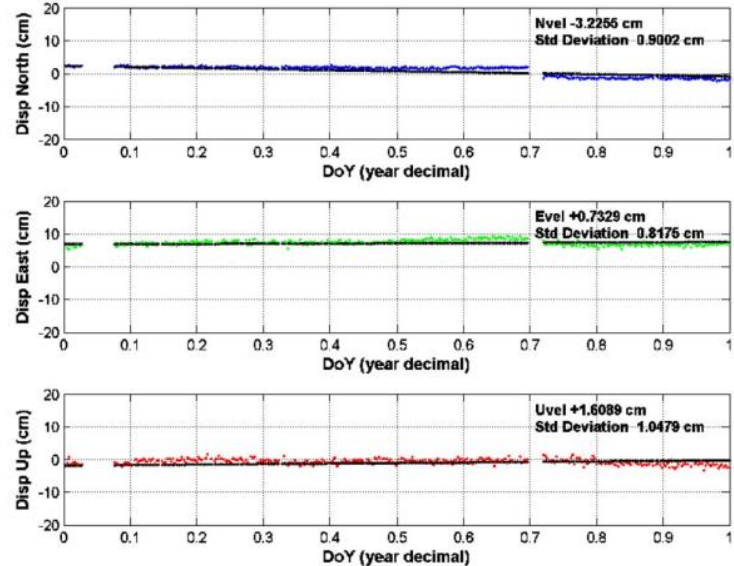

Figure 8. Improved GPS-derived CTS at KUKP after removal of outliers.

\begin{tabular}{|c|c|c|c|c|c|c|c|c|c|}
\hline \multirow{2}{*}{ Station } & \multicolumn{3}{|c|}{ Observed } & \multicolumn{3}{c|}{ Computed } & \multicolumn{3}{c|}{ Residual } \\
\cline { 2 - 10 } & $V_{n}(\mathrm{~mm} / \mathrm{yr})$ & $V e(\mathrm{~mm} / \mathrm{yr})$ & $V u(\mathrm{~mm} / \mathrm{yr})$ & $V n(\mathrm{~mm} / \mathrm{yr})$ & $V e(\mathrm{~mm} / \mathrm{yr})$ & $V u(\mathrm{~mm} / \mathrm{yr})$ & $V \mathrm{n}(\mathrm{mm} / \mathrm{yr})$ & $V e(\mathrm{~mm} / \mathrm{yr})$ & $V u(\mathrm{~mm} / \mathrm{yr})$ \\
\hline LGKW & 31.349 & 59.577 & -13.209 & 30.054 & 61.086 & -9.929 & 1.295 & -1.509 & -3.28 \\
USMP & 43.199 & 233.718 & 26.126 & 44.214 & 232.188 & 17.649 & -1.015 & 1.53 & 8.477 \\
TOKA & 36.295 & 219.348 & 9.118 & 36.115 & 217.973 & 7.758 & 0.18 & 1.375 & 1.36 \\
SGPT & 25.434 & 65.477 & -6.711 & 24.923 & 67.165 & -4.668 & 0.511 & -1.688 & -2.043 \\
BABH & 38.461 & 229.929 & 7.075 & 39.332 & 228.548 & 6.146 & -0.871 & 1.381 & 0.929 \\
UUMK & 26.507 & 81.177 & -14.973 & 25.401 & 81.812 & -11.371 & 1.106 & -0.635 & -3.602 \\
PUPK & 27.315 & 227.038 & 0.777 & 28.006 & 225.768 & 0.863 & -0.691 & 1.27 & -0.086 \\
SIK1 & 25.029 & 63.47 & -6.322 & 24.313 & 65.191 & -4.393 & 0.716 & -1.721 & -1.929 \\
TLKI & 13.727 & 212.056 & 16.378 & 13.874 & 210.686 & 13.938 & -0.147 & 1.37 & 2.44 \\
LASA & 22.267 & 208.777 & 23.815 & 22.439 & 207.333 & 19.641 & -0.172 & 1.444 & 4.174 \\
\hline
\end{tabular}

Table 1. The difference between observed and computed velocities for ten (10) sites in Peninsular Malaysia region from year 2012.

Forty-one (41) stations of MyRTKnet in Peninsular Malaysia region in 2012 is illustrated in Figure 9. This 2012 session had the most significant value of velocities compares to the other year session. The range of velocities were between $1 \mathrm{~mm} / \mathrm{yr}$ to $233 \mathrm{~mm} / \mathrm{yr}$ and $1 \mathrm{~mm} / \mathrm{yr}$ to $31 \mathrm{~mm} / \mathrm{yr}$ for horizontal and vertical component respectively. The horizontal and vertical precision of estimated site was found at average of $4.6 \mathrm{~mm}$ and $7.3 \mathrm{~mm}$, respectively. From Figure 9, it can be observed that the site velocity at southern of the region moved in southeastward and gradually moving to northeastward for site velocity at northern region. Similar to the study that found by Wan Aris (2018), one can inspect inhomogeneous direction of intra-plate velocities from Peninsular Malaysia region MyRTKnet sites in northern to southern part that moved horizontally southeastward.

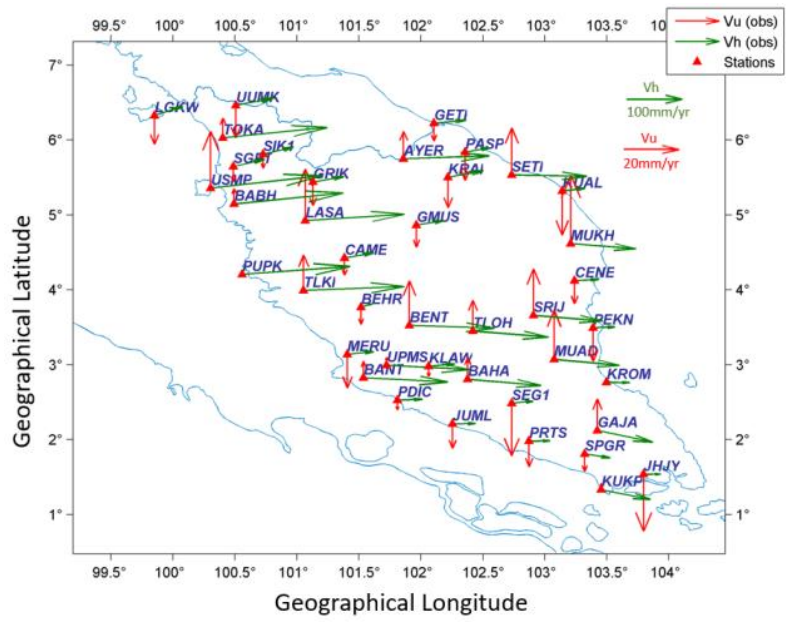

Figure 9. Site velocities in Peninsular Malaysia as estimated from forty-one (41) MyRTKnet sites in 2012

For the validation on the site velocities, the observed velocities were compared with the computed velocities as in Table 1 . Ten (10) MyRTKnet sites in Peninsular Malaysia from 2012 were 
chosen for result and discussion purpose on site velocities validation. From the Table 1 , it can be observed that the residual between observed and computed velocities were found at average $0.18 \mathrm{~mm} / \mathrm{yr}$ and $0.6 \mathrm{~mm} / \mathrm{yr}$ for horizontal and vertical components respectively.

In East Malaysia region, twenty-three (23) stations of MyRTKnet from 2012 were selected for site velocities estimation as shown in Figure 10. The range of velocities were between $-46.6 \mathrm{~mm} / \mathrm{yr}$ to $62.5 \mathrm{~mm} / \mathrm{yr}$ and $-25.5 \mathrm{~mm} / \mathrm{yr}$ to $9.7 \mathrm{~mm} / \mathrm{yr}$ for horizontal and vertical component respectively. The horizontal and vertical precision of estimated site was found at average of $3.6 \mathrm{~mm}$ and $7.8 \mathrm{~mm}$, respectively. From Figure 10, it can be observed that all the site velocities at Sabah and Sarawak region moved in southeastward. Mustafar (2014) stated that position time series in ITRF2008 were used to estimate station velocities using linear regression resulting the direction of velocity of North Borneo stations toward southeast ward.

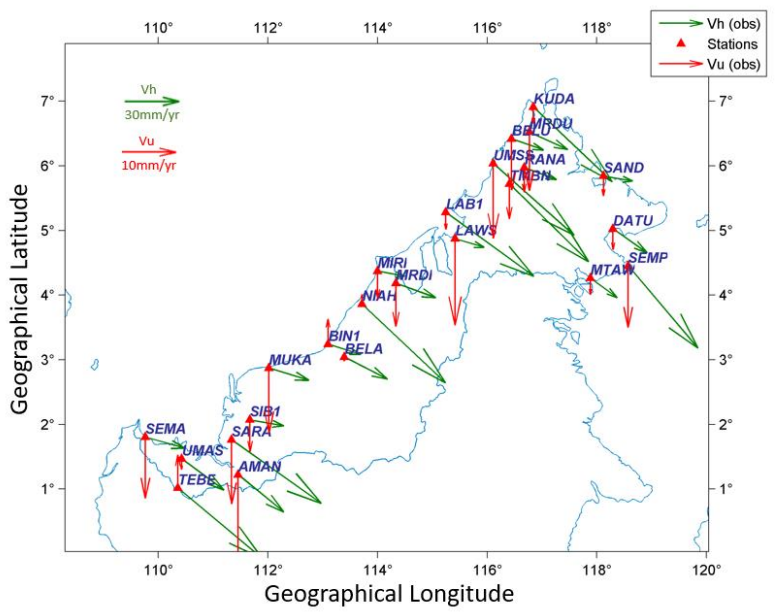

Figure 10. Site velocities in Sabah and Sarawak as estimated from twenty-three (23) MyRTKnet sites in 2012

To validate the site velocities, the observed velocities were compared with the computed velocities as in Table 2. Ten (10) MyRTKnet sites in Sabah and Sarawak from year 2012 were selected for this discussion. It can be observed that the residual between observed and computed velocities were found at average $-1 \mathrm{~mm} / \mathrm{yr}$ and $0.4 \mathrm{~mm} / \mathrm{yr}$ for horizontal and vertical components respectively.

\begin{tabular}{|c|r|r|r|}
\hline \multirow{2}{*}{ Station } & \multicolumn{3}{|c|}{ Residual } \\
\cline { 2 - 4 } & $\mathrm{Vn}(\mathrm{mm} / \mathrm{yr})$ & $\mathrm{Ve}(\mathrm{mm} / \mathrm{yr})$ & $\mathrm{Vu}(\mathrm{mm} / \mathrm{yr})$ \\
\hline SEMA & 1.221 & -3.156 & 4.767 \\
\hline TEBE & 1.809 & -3.956 & -4.847 \\
UMAS & 1.158 & -2.59 & -1.798 \\
SARA & 1.579 & -4.478 & 3.437 \\
MRDU & 2.309 & -7.381 & 5.22 \\
KUDA & 1.697 & -4.428 & -1.244 \\
MTAW & 1.619 & -1.935 & -1.835 \\
SAND & 0.819 & -1.901 & -1.259 \\
DATU & 2.599 & -2.645 & -1.106 \\
\hline SEMP & 2.151 & -4.328 & 3.332 \\
\hline
\end{tabular}

Table 2. The difference between observed and computed velocities for ten (10) sites in Sabah and Sarawak region from year 2012

Quasi Network points in Peninsular Malaysia were generated at $0.3^{\circ} \times 0.3^{\circ}$ or $15 \mathrm{~km} 2$ of spatial resolution. As illustrated in Figure 11, there are 144 Quasi Network points generated to cover the inland area of Peninsular Malaysia bounded within $1^{\circ} \mathrm{N}-7^{\circ} \mathrm{N}$ and $99^{\circ} \mathrm{E}-104.5^{\circ} \mathrm{E}$ (from Q1 until Q144 situated in the northwestern and southeastern part of the region, respectively).

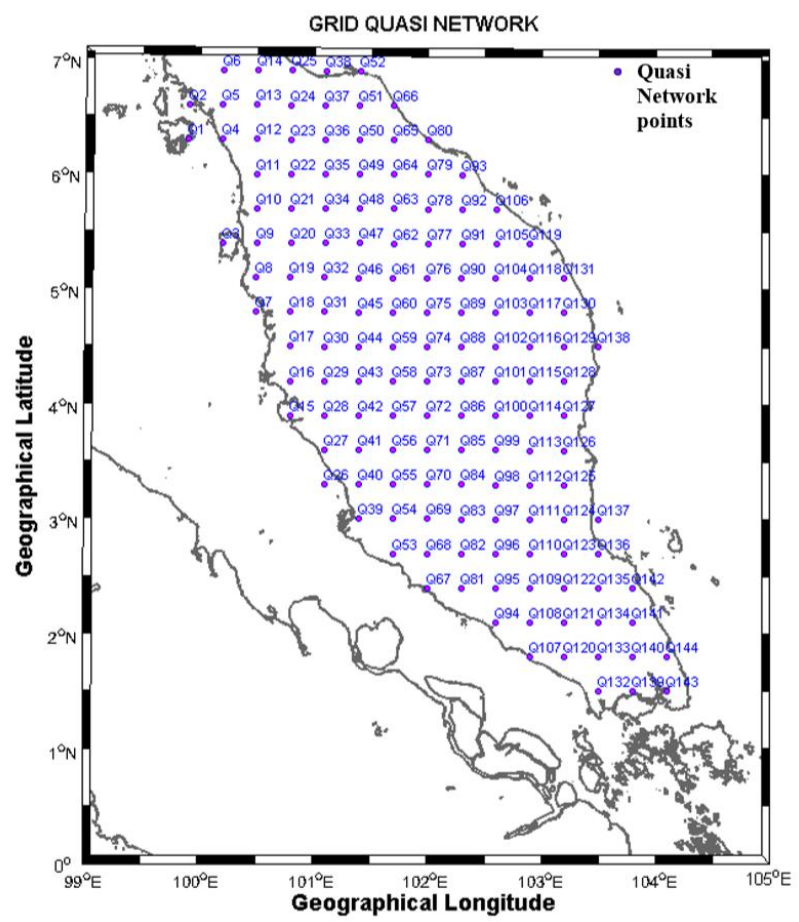

Figure 11. Quasi Network points in Peninsular Malaysia with $0.3^{\circ} \times 0.3^{\circ}(\sim 15 \mathrm{~km} 2)$ spatial resolution from $(\mathrm{Q} 1-\mathrm{Q} 144)$.

In Sabah and Sarawak region, Quasi Network prediction with $0.3^{\circ} \times 0.3^{\circ}$ grid were performed within the inland area bounded within $0.5^{\circ} \mathrm{N}-7.5^{\circ} \mathrm{N}$ and $109^{\circ} \mathrm{E}-119.5^{\circ} \mathrm{E}$ as illustrated in Figure 11. From the figure, 197 Quasi Network points were generated to cover the inland region of Sabah and Sarawak (from q1 until q197 situated in the west and eastern part of the region, respectively).

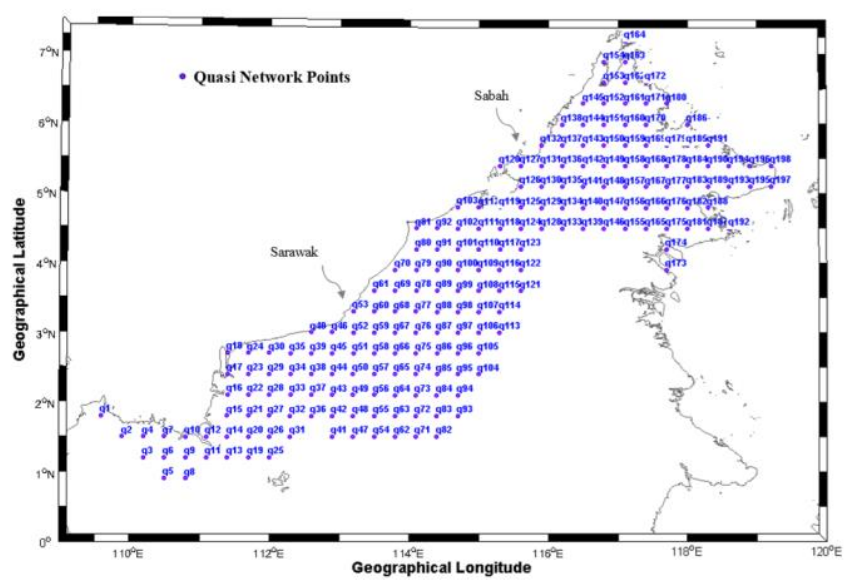

Figure 11. Quasi Network points in Sabah and Sarawak with $0.3^{\circ} \times 0.3^{\circ}(\sim 15 \mathrm{~km} 2)$ grid from $\mathrm{q} 1-\mathrm{q} 197$.

Figure 12 illustrates the variability of these compression and extension at Quasi Network points during the period within the Peninsular Malaysia region Red and blue crosses represent the compression and extension, respectively at location of Quasi Network. The Quasi Network point denoted by Q1-Q144 in black and grey font represents 'ideal' and 'remote' points, respectively. 


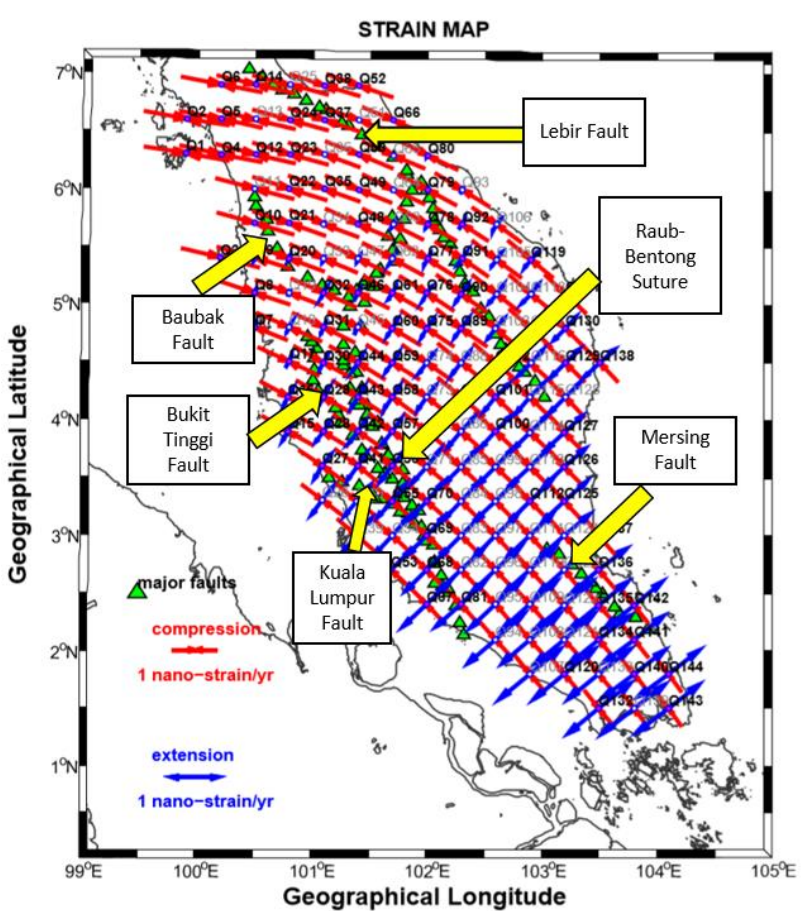

Figure 12. Strain rate map over Peninsular Malaysia in 2004.

The principal strain from year 2004 to 2013 was found to be visible in the Peninsular Malaysia and several fault zones with small magnitudes of less than 1 nano-strain/yr except in year 2004 and 2012 as in Figure 12 and Figure 13 respectively. The result found that the principal strain on year 2004 and 2012 were significantly higher than the rest.

From the Figure 12, the principal strain in the north, northwest and northeast of the region was found to be dominated by large compression strain with magnitude in range of 1 to 1.52 nanostrain/yr. In contrast, the south and west coast regions were dominated by large extension strain in range of 0.7 to 1.37 nano-strain/yr. Based on Figure 13, the principal strain in the north, northwest and northeast of the region was found to be dominated by large compression strain with magnitude in range of 1 to 2.32 nano-strain/yr while the south, east and west coast regions were dominated by large extension strain in range of 0.8 to 2.1 nano-strain/yr.

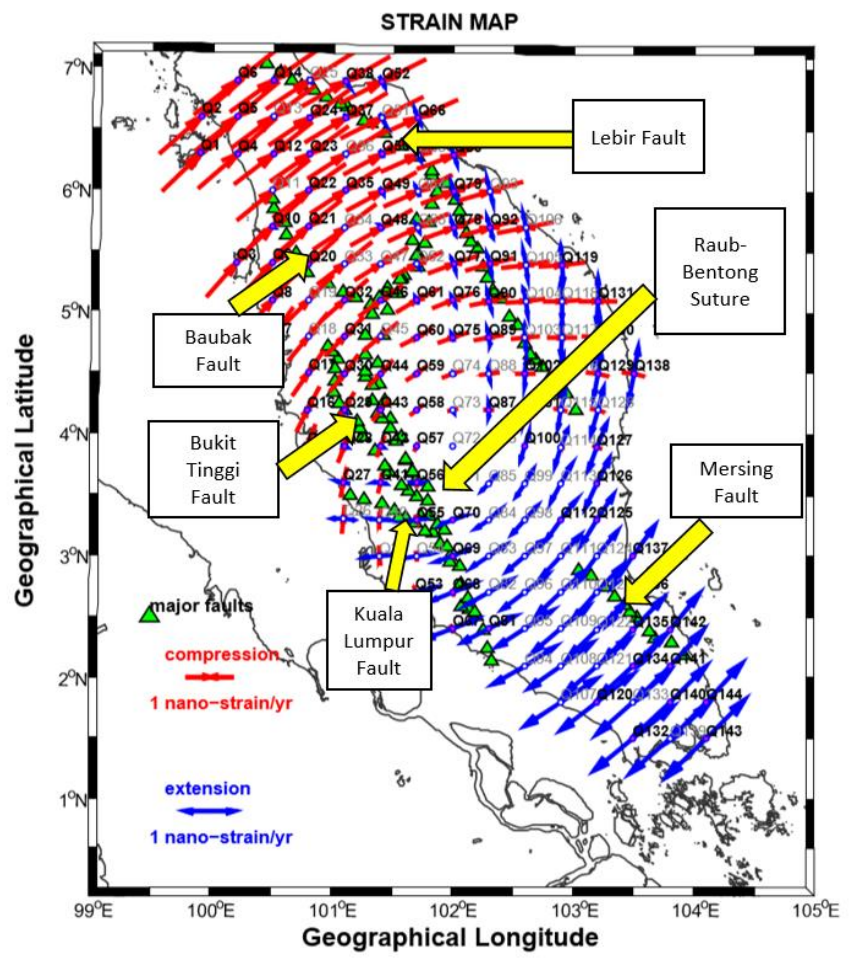

Figure 13. Strain rate map over Peninsular Malaysia in 2012.

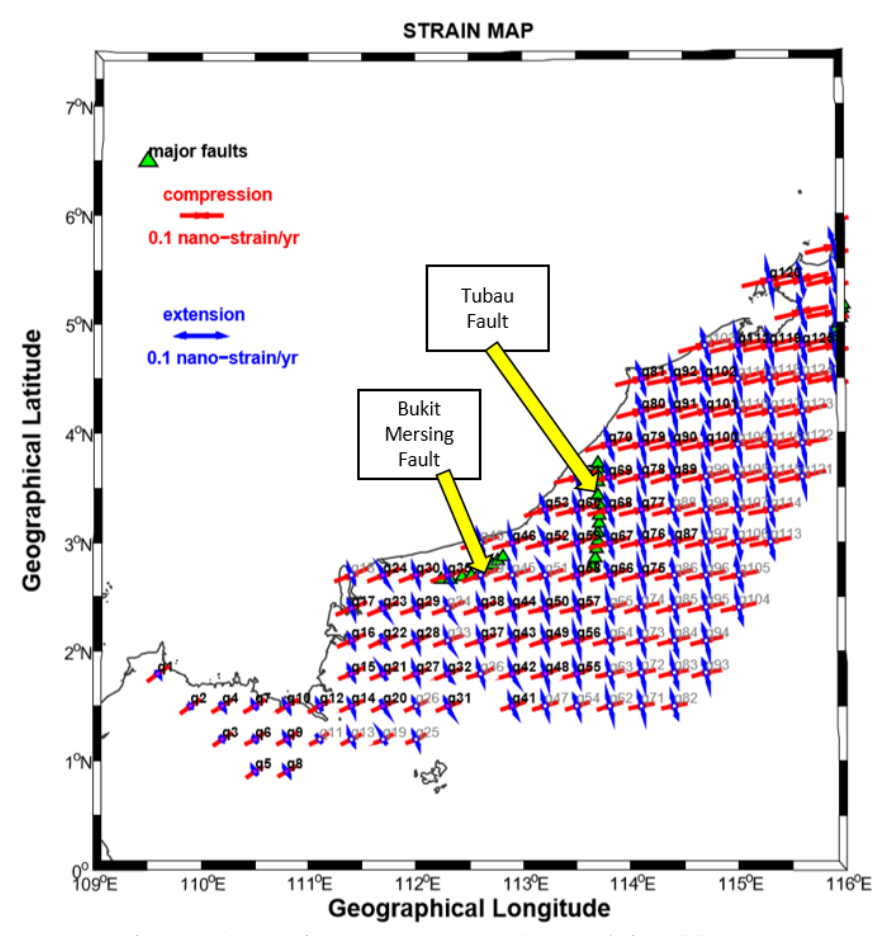

Figure 14. Strain rate map over Sarawak in 2007. 


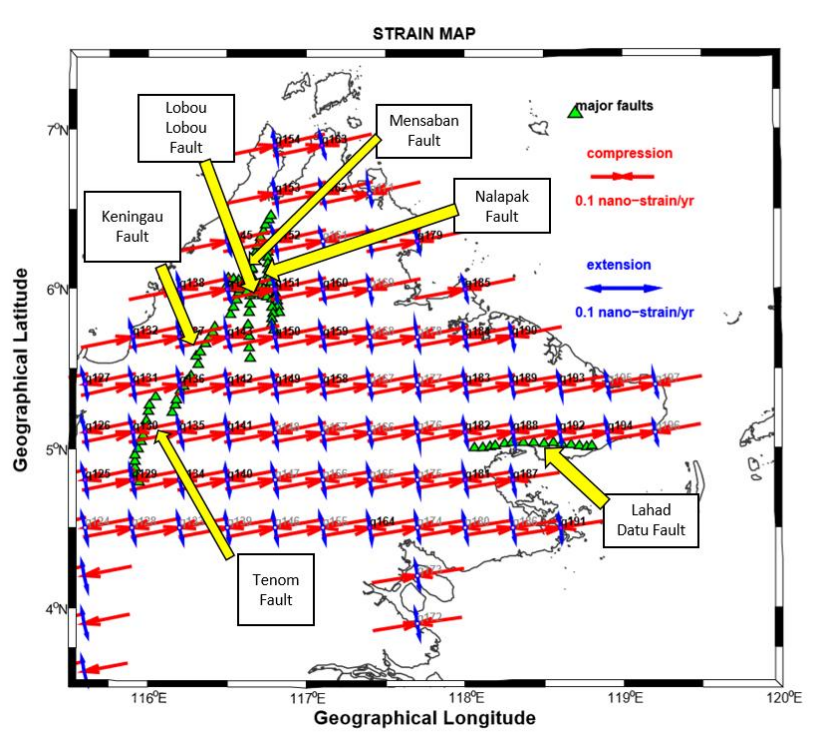

Figure 15. Strain rate map over Sarawak in 2007.

The principal strain from year 2007 to 2013 was found to be visible in the Sabah and Sarawak with small magnitudes of less than 0.1 nano-strain/yr. However in year 2007, as shown in Figure 14 and Figure 15, the results indicate that the principal strain on year 2007 were significantly higher compare to the rest. From the Figure 14, the principal strain in the Sarawak region was found to be dominated by large compression strain with magnitude in range of 0.05 to 0.12 nano-strain/yr. In contrast, the principal strain in the Sabah region as in Figure 15, have even larger compression strain with magnitude in range of 0.1 to 0.13 nano-strain/yr. According to Yong (2016), North Borneo represents the stable part of the Sundaland plate as it has a low level of deformation and shear strain rate.

In addition, the strain rates contour of the region from 20042013 that consists of extension rate and compression rate were generated. The pattern of strain rates is presented as coloured contour as illustrated in Figure 16, Figure 17, Figure 18 and Figure 19. From Figure 16 it shows that most of the highest extension rates changes in the southern and eastcoast part of Peninsular Malaysia at 0.15 nano-strain/yr. Meanwhile in Figure 17, the eastcoast and northern part of Peninsular Malaysia experienced the highest compression rate changes at 0.02 nano-strain/yr.

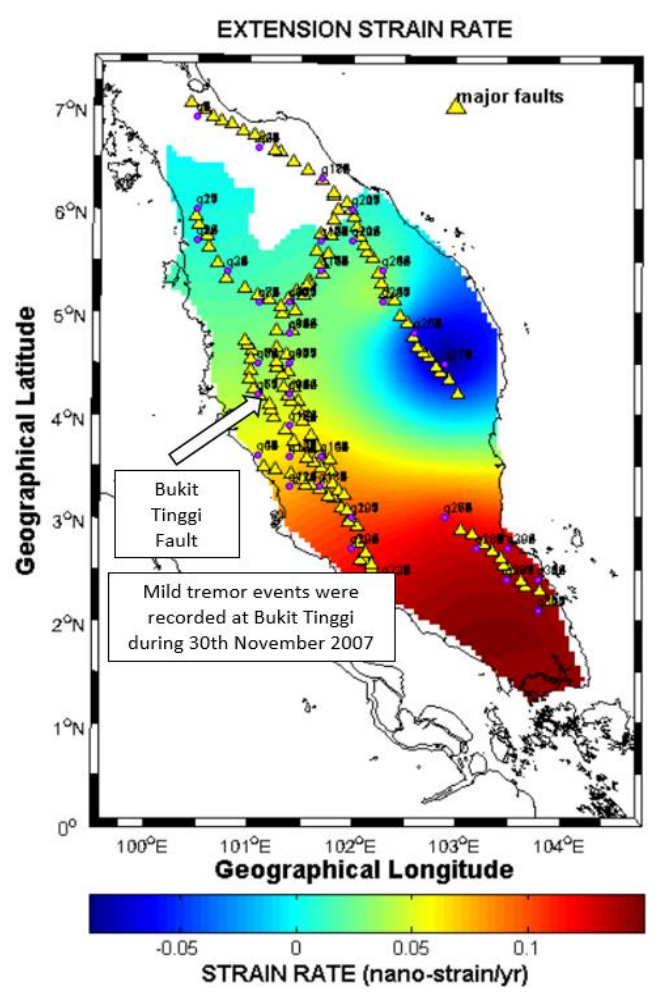

Figure 16. Strain rate (Extension) map contour over Peninsular Malaysia (2004-2013).

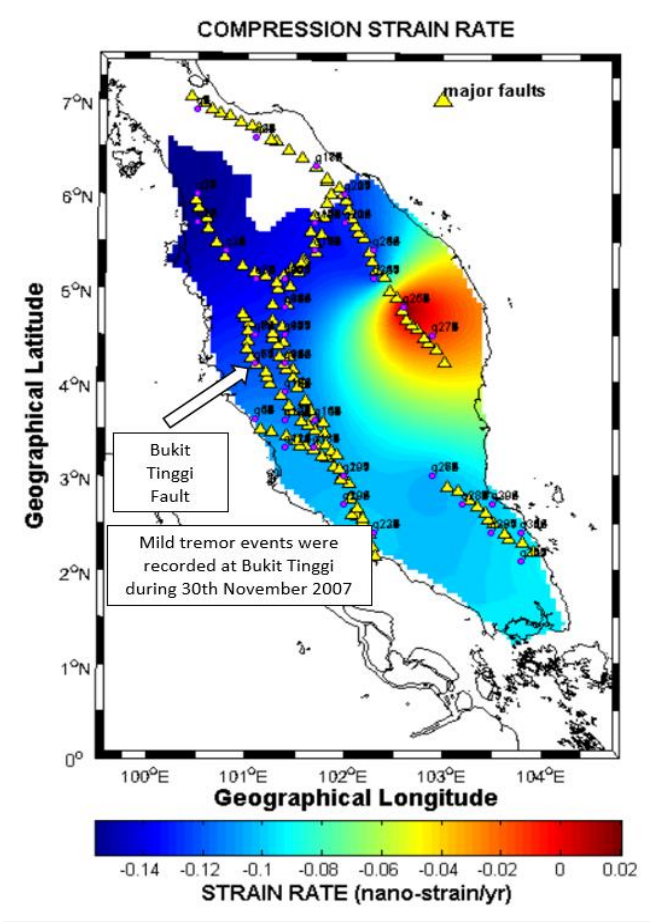

Figure 17. Strain rate (Compression) map contour over Peninsular Malaysia (2004-2013).

Based on Figure 18, the changes of extension rates in the Sabah region Peninsular Malaysia were particularly small, which mostly affected on the western part of the region. In contrast, Figure 19 shows even higher compression rate changes especially the eastern part of Sabah at 2 nano-strain/yr. 
Throughout the year from 2007 to 2013, it is noted that there were several local earthquakes occurred at the eastern part of Sabah. The earthquakes were from 2008, 2010 and 2012 with the magnitude of $4.5 \mathrm{Mw}, 5.0 \mathrm{Mw}, 4.2 \mathrm{Mw}$ and $4.6 \mathrm{Mw}$.

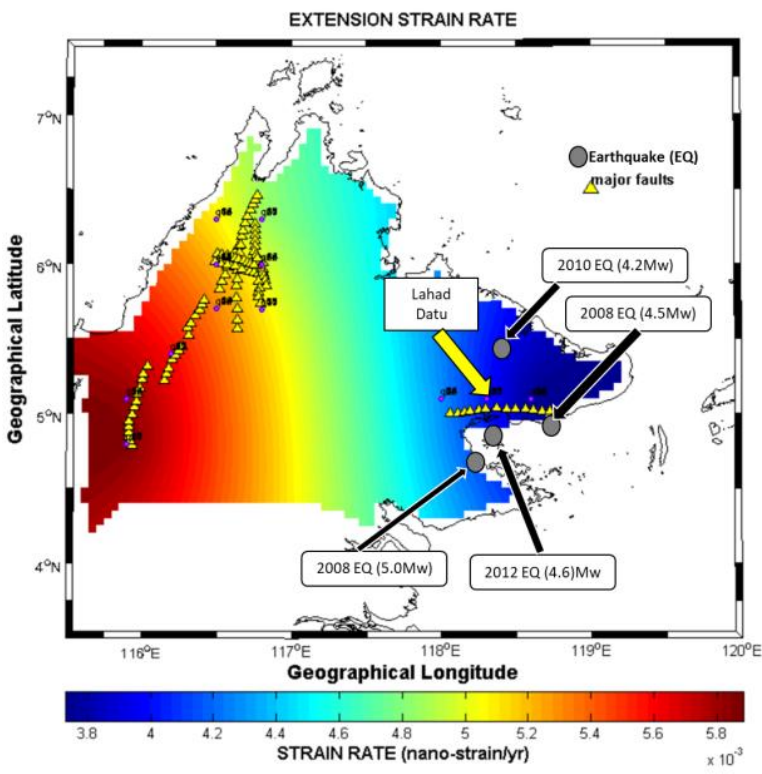

Figure 18. Strain rate (Extension) map contour over Sabah (2004-2013).

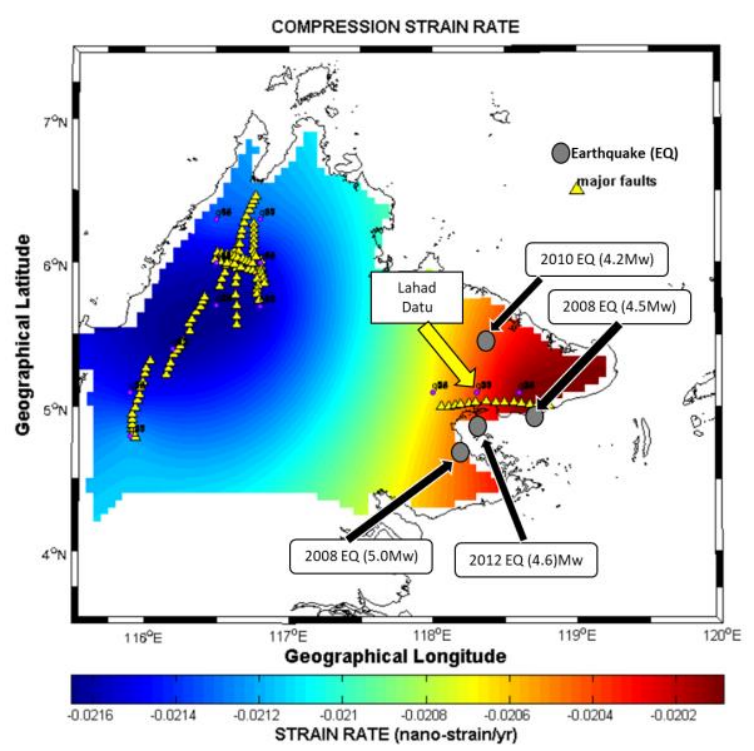

Figure 19. Strain rate (Compression) map contour over Sabah (2004-2013).

In order to study the behavior of the fault line in Peninsular Malaysia, Quasi Network points on Bukit Tinggi fault were selected as Shuib (2009) stated the fault were suspect to be highly associated with seismic events. For North Borneo region, Quasi Network points on Lahad Datu fault were selected as Tongkul (2017) stated that The latest study on active faults by UMS in collaboration with other public universities (UM, UKM, UiTM, UCSI, UTM) and government agencies (JMG, MetMalaysia, ARSM, JKR) using high resolution radar images
(IFSAR) and satellite images coupled with field observations identified several active fault zones in Ranau and Lahad Datu areas. Graphs on the extension and compression rate changes were generated as shown in Figure 20, Figure 21, Figure 22 and Figure 23.

For Bukit Tinggi fault, Quasi Network point (Q29, Q30, Q41 and $\mathrm{Q} 42$ ) were chosen prior to the location near to the fault. From Figure 3.15 and Figure 3.16, the highest change of strain rate happened on two (2) different timeframes. The first significant change happened during 2004 until 2006 while the second time during 2011 until 2013. It is believed that the Sumatera earthquakes such as 2004 Sumatera earthquake (9.1Mw), 2005 Sumatera earthquake (8.6Mw), 2010 Mentawai Island earthquake $(7.8 \mathrm{Mw})$ and double 2012 Sumatera earthquakes $(8.2 \mathrm{Mw}$ and $8.6 \mathrm{Mw})$ were responsible for rapid changes in strain rate at Peninsular Malaysia region. For the case of Bukit Tinggi's tremors in 2007, Figure 3.16 shows a slight changes of compression rate pattern during that period. Although a few major faults have been identified within the Peninsular Malaysia, only minor earthquakes from Bukit Tinggi faults have produced notable ground motion, and thus only the six events with magnitude $\mathrm{Mw}>2.4$ were considered as mentioned by Loi (2018).

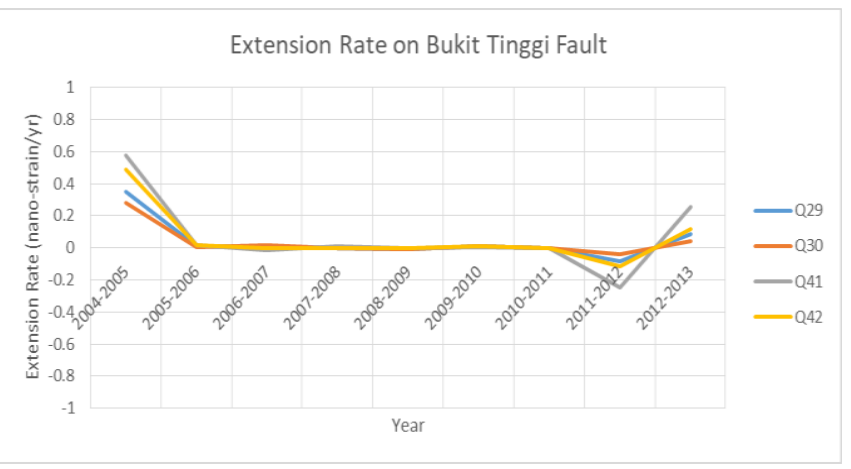

Figure 20. Extension rate changes on Bukit Tinggi Fault's Quasi Network points (Q29, Q30, Q41 and Q42) from 2004 to 2013.

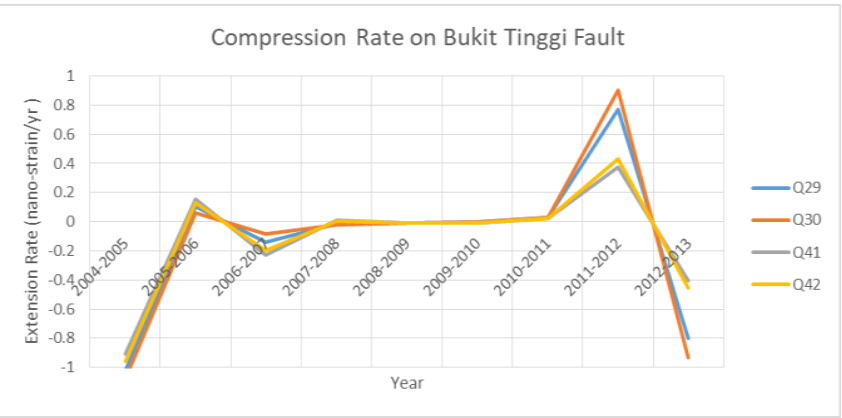

Figure 21. Compression rate changes on Bukit Tinggi Fault's Quasi Network points (Q29, Q30, Q41 and Q42) from 2004 to 2013.

To study Lahad Datu fault, Quasi Network point (q182, q188 and q192) were selected. Based on Figure 22, the most significant extension rate changes happened from 2011-2013. In contrast, the highest compression rate changes occurred in the period from 2007 to 2009 as shown in Figure 23. It is noted that 
there were severals local earthquakes occurred nearby Lahad Datu. Hence, it can be speculated that the Lahad Datu fault was heavily influenced by the seismic events. The result consistent with finding by Tongkul (2017) stated that, Lahad Datu-Tawau area and its vicinity exhibit numerous linear features $(20-40 \mathrm{~km}$ in length), highly associated with earthquakes.

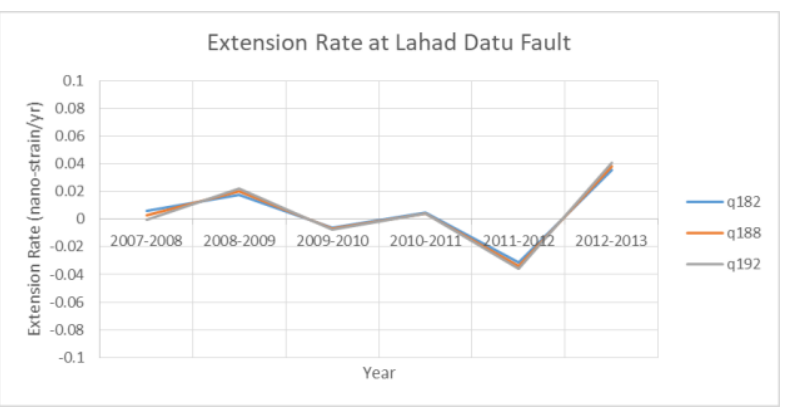

Figure 22. Extension rate changes on Lahad Datu Fault's Quasi Network points (q182, q188 and q192) from 2007 to 2013.

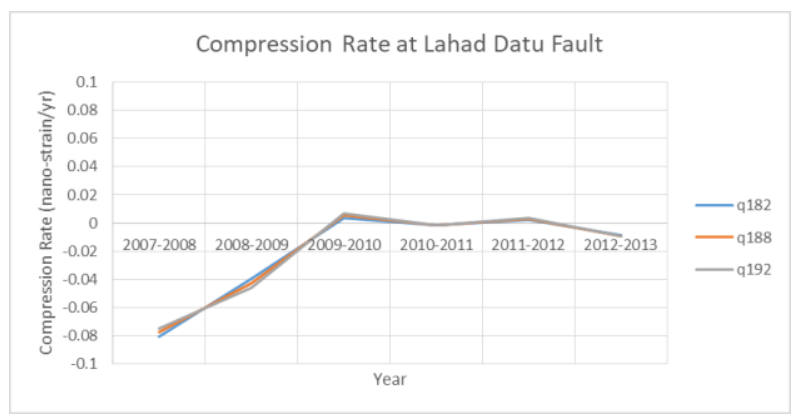

Figure 23 Compression rate changes on Lahad Datu Fault's Quasi Network points (q182, q188 and q192) from 2007 to 2013.

\section{CONCLUSION}

In this study, a set of strain maps that consists of Peninsular Malaysia, Sabah and Sarawak from 2004 until 2013 have been generated and analyzed properly in order to provide crustal deformation information on the study area. These long-term strain maps derived from GPS data provide the actual trend of crustal deformation in Malaysia. From the study, several conclusions of the result can be remarked. Despite of mild tremor event in Bukit Tinggi as reported on November 2007, the strain rate analysis show in slow local tectonic movement within the area.

However, this slow but significant local tectonic movement of the area has to be further investigated. For future outlook, these results should be corroborated not only with seismic events but with the seismic data from the related agencies in order to make it more practical and relevant. These sets of strain map also can be compiled in the form of seismic catalog so these will benefit for researchers in related field. The strain map will enable for categorizing seismic zone within the area that will be useful for geohazard management.

\section{ACKNOWLEDGEMENTS}

The author would like to express gratitude toward Jabatan Ukur dan Pemetaan Malaysia (JUPEM) in providing MyRTKnet data for this study. The author also would like to channel an appreciation towards Kementerian Pengajian Tinggi (KPT) and Fundamental Research Grant Scheme (FRGS) - Vote No. 4F962 and 4F189 for funding this study.

\section{REFERENCES}

Bauer, M. W. (2014). A word from the Editor on the special issue on 'Public Engagement'. Public Understanding of Science, 23(1), 3-3. doi:10.1177/0963662513518149Ozkurt,

Boschi, E., Giardini, D., Pantosti, D., Valensise, G., Arrowsmith, R., Basham, P., ... Yeats, R. S. (1996). New trends in active faulting studies for seismic hazard assessment. Annali di Geofisica, 39(6), 1301-1307.

Cabanas, L., Rivas-Medina, A., Martinez-Solares, J. M., Gaspar-Escribano, J. M., \& Bento, B. (2015). Relationships Between Mw and Other Earthquake Size Parameters in the Spanish IGN Seismic Catalog. Pure and Applied Geophysics, 172, 2397-2410. doi 10.1007/s00024-014-1025-2

Chamot-Rooke, N., \& Pichon, X. L. (1999). GPS determined eastward Sundaland motion with respect to Eurasia confirmed by earthquakes slip vectors at Sunda and Philippine trenches. Earth and Planetary Science Letters, 173(4), 439-455. doi:10.1016/s0012-821x(99)00239-3

Durant J.R ,Evans G.A. and Thomas G.P.,1989, 'The Public Understanding of Science.' Nature, 340,1981, Paris Edition

Feng, L., Hill, E. M., Banerjee, P., Hermawan, I., Tsang, L. L., Natawidjaja, D. H., . . . Sieh, K. (2015). A unified GPS-based earthquake catalog for the Sumatran plate boundary between 2002 and 2013. Journal of Geophysical Research: Solid Earth, 120(5), 3566-3598. doi:10.1002/2014jb011661

Gomez, A. S., Bouin, M. N., Collilieux, X., \& Woppelmann, G. (2011). Correlated errors in GPS position time series: Implications for velocity estimates. Journal of Geophysical Research: Solid Earth, 116(B1). doi:https://doi.org/10.1029/2010JB007701

Gourdarzi, M.A., Cocard, M., Santerre, R. (2015). GeoStrain: An open source software for calculating crustal strain rates. Journal of Computers \& Geosciences. 0098-3004/\& 2015 Elsevier Ltd. doi.org/10.1016/j.cageo.2015.05.007.Koutsia,

Guy, M., Earle, P., Ostrum, C., Gruchalla, K., \& Horvath, S. (2010). Integration and Dissemination of Citizen Reported and Seismically Derived Earthquake Information via Social Network Technologies. Lecture Notes in Computer Science Advances in Intelligent Data Analysis IX, 42-53. doi:10.1007/978-3-642-13062-5_6

Jenny, S., Goes, S., Giardini, D., \& Kahle, H. (2004). Earthquake recurrence parameters from seismic and geodetic strain rates in the eastern Mediterranean. Geophysical Journal International, 157(3), 1331-1347. doi:10.1111/j.1365246x.2004.02261.x 
Kadir, M., Shahrum, S., Kamaludin, O., Ghazali, D., Abdullah, H.O., 2003. Geocentric Datum GDM2000 for Malaysia: implementation and implications. Technical Paper, $15 \mathrm{pp}$.

Komoo, I. (2018, October 12). Malaysia kian dihampiri jalur gempa bumi? BH Online. Retrieved from https://www.bharian.com.my/kolumnis//malaysia-kiandihampiri-jalur-gempa-bumi

Kotsakis, Christopher. (2007). Least-squares collocation with covariance-matching constraints. Journal of Geodesy. 81. 661677. 10.1007/s00190-007-0133-5.

Loi, D. W., Raghunandan, M. E., \& Swamy, V. (2018). Revisiting seismic hazard assessment for Peninsular Malaysia using deterministic and probabilistic approaches. Natural Hazards and Earth System Sciences, 18(9), 2387-2408. doi:10.5194/nhess-18-2387-2018

Malaysia, Jabatan Ukur dan Pemetaan, JUPEM. (2005). MALAYSIAN RTK GPS NETWORK (MyRTKnet) GUIDELINE (Vol. 9). Kuala Lumpur, Kuala Lumpur: JUPEM.

Moritz, H. (1978), Least- squares collocation, Rev. Geophys., 16(3), 421-430, doi:10.1029/RG016i003p00421.

Musacchio, G., Falsaperla, S., Sansivero, F., Ferreira, M. A., Oliveira, C. S., Nave, R., \& Zonno, G. (2015). Dissemination strategies to instil a culture of safety on earthquake hazard and risk. Bulletin of Earthquake Engineering, 14(7), 2087-2103. doi:10.1007/s10518-015-9782-6

Mustafar, Mohamad Asrul \& Simons, Wim \& Omar, Kamaludin \& A C Ambrosius, Boudewijn. (2014). Monitoring of Local Deformations in North Borneo.

Mustafar, M. A., Simons, W. J., Tongkul, F., Satirapod, C., Omar, K. M., \& Visser, P. N. (2017). Quantifying deformation in North Borneo with GPS. Journal of Geodesy, 91(10), 12411259. doi:10.1007/s00190-017-1024-z

Simons, W. J., Socquet, A., Vigny, C., Ambrosius, B. A., Abu, S. H., Promthong, C., . . . Spakman, W. (2007). A decade of GPS in Southeast Asia: Resolving Sundaland motion and boundaries. Journal of Geophysical Research, 112(B6). doi:10.1029/2005jb003868

The Ministry of Water, Land and Natural Resources, Department of Mineral and Geoscience (JMG). (2018). Insiden Bunyi Bising dan Gegaran yang Dirasai di Sekitar Bandaraya Ipoh, Perak Pada 4 Oktober 2018 [Press release]. Putrajaya, Selangor: KATS: Author.

Tongkul, F. (2017). Active tectonics in Sabah - seismicity and active faults. Bulletin of the Geological Society of Malaysia, 64, 27-36. doi:10.7186/bgsm64201703

Wan Aris, W. (2018). Spatio-Temporal Crustal Deformation Model of Sundaland In Malaysia Using Global Positioning System (PhD's thesis, Universiti Teknologi Malaysia, 2018) (pp. 1-359). Johor Bahru: UTM.

Wan Aris, Wan \& Musa, Tajul \& Omar, Kamaludin \& Omar, Abdullah. (2018). Non-Linear Crustal Deformation Modeling for Dynamic Reference Frame: A Case Study in Peninsular
Malaysia. International Federation of Surveyors, FIG 2018, Istanbul, Turkey.

Wheeler, R.L. (2014). Earthquake catalog for estimation of maximum earthquake magnitude, Central and Eastern United States: Part B, historical earthquakes. Open-File Report. doi:10.3133/ofr20141025b

Wu, Y.Q., Jiang, Z.S., Yang, G., Wei, W., Liu, X. (2011). Comparison of GPS strain rate computing methods and their reliability. Geophys. J. Int. 185, 703-717.

Yazdi, P., \& Zare, M. (n.d.). Building an Earthquake Catalog for The Middle East. In 15 WCEE LISBOA 2012. Retrieved December $10, \quad 2018, \quad$ from https://www.iitk.ac.in/nicee/wcee/article/WCEE2012_5675.pdf

Yong, C., Denys, P., \& Pearson, C. (n.d.). An insight into present-day deformation of the Sundaland plate from GPS CORS measurements (G51A-1069). In AGU FALL MEETING. Retrieved May 19, 2019, from https://agu.confex.com/agu/fm16/mediafile/Handout/.../AGU_p oster_final.pdf

Zhu, S., \& Shi, Y. (2011). Estimation of GPS strain rate and its error analysis in the Chinese continent. Journal of Asian Earth Sciences, 40, 351-362. doi:10.1016/j.jseaes.2010.06.007

Revised August 2019 